\title{
Efek Perbedaan Dataran terhadap Produksi Karkas Ayam Broiler yang Dipelihara di Kandang Closed House
}

\author{
Effect of Differences in Plains on Carcass Production of Broiler Chickens Raised in Closed \\ House Cages
}

\section{F. Nurhidayat, L. D. Mahfudz, dan D. Sunarti}

Fakultas Peternakan dan Pertanian Universitas Diponegoro

Corresponding e-mail: fauzannurhidayat1997@gmail.com

\begin{abstract}
This research was conducted in a closed house cage that has the same Standard Operation Procedure (SOP), the closed house used came from different areas: Demak (lowland), Gunungpati (plain) and Ampel (plateus) areas. The purpose of this study was to determine the effect of macroclimate on microclimate and broiler carcass production. This study used a Completely Randomized Design (CRD) with 3 treatments (T1: Maintenance of broiler in Demak, T2: maintenance in Gunungpati and T3: maintenance in Ampel.) and 8 replications. Data were processed using analysis of variance at a significance level of 5\%, if the treatment had a significant effect followed by Duncan's Multiple Range Test. Statistical test results showed that the difference in plains had a significant effect $(\mathrm{P}<0.05)$ on cutting weights, namely at lowlands $1560.13 \mathrm{~g}$ (a) better than medium plains $1477.94 \mathrm{~g}$ (b) and highlands $1454.38 \mathrm{~g}$ (b). Carcass weights also had a significant effect $(\mathrm{P}<0.05)$, namely in the lowlands of $1060.58 \mathrm{~g}$ (a) better than the moderate plains of $1029.11 \mathrm{~g}(\mathrm{ab})$, and plateaus of $1006.01 \mathrm{~g} \mathrm{(b).}$ Percentage of carcass, abdominal fat and carcass quality had no significant effect $(\mathrm{P}>0.05)$. Based on the research conducted, it can be concluded that the difference in terrain influences the microclimate conditions of the cage, thus producing the best cut weight and broiler chicken carcass production in the lowlands.
\end{abstract}

Key words: broiler, closed house, altitude, performance.

\begin{abstract}
ABSTRAK
Penelitian ini dilaksanakan pada kandang closed house yang yang memiliki Standard Operation Procedure (SOP) sama, closed house yang digunakan berasal dari dataran yang berbeda yaitu: didataran rendah, sedang dan tinggi. Tujuan penelitian ini adalah untuk mengetahui pengaruh makroklimat terhadap mikroklimate dan produksi karkas ayam broiler. Penelitian ini menggunakan Rancangan Acak Lengkap (RAL) dengan 3 perlakuan (T1: Pemeliharaan ayam di Demak, T2: pemeliharaan di Gunungpati dan T3: pemeliharaan di Ampel.) dan 8 ulangan. Data diolah menggunakan analisis ragam pada taraf signifikasi 5\%, jika perlakuan berpengaruh nyata nyata dilanjutkan dengan Uji Wilayah Ganda Duncan. Hasil uji statistik menunjukkan bahwa perbedaan dataran berpengaruh nyata $(\mathrm{P}<0,05)$ terhadap bobot potong yaitu pada dataran rendah $1560.13 \mathrm{~g}$ (a) lebih baik dari dataran sedang 1477,94g (b) dan dataran tinggi 1454,38g (b). Bobot karkas juga berpengaruh nyata $(\mathrm{P}<0,05)$ yaitu pada dataran rendah $1060.58 \mathrm{~g}$ (a) lebih baik dari dataran sedang 1029.11g (ab), dan dataran tinggi 1006,01g (b). Persentase karkas, lemak abdominal dan kualitas karkas tidak berpengaruh nyata $(\mathrm{P}>0,05)$. Berdasarkan penelitian yang dilakukan dapat disimpulkan bahwa perbedaan dataran berpengaruh terhadap kondisi mikroklimat kandang, sehingga menghasilkan bobot potong dan produksi karkas ayam broiler yang paling baik pada dataran rendah.
\end{abstract}

Kata kunci : broiler, closed house, dataran, produksi karkas

\section{PENDAHULUAN}

Indonesia merupakan daerah yang beriklim tropika dengan rata-rata suhu harian $25,2-27,9^{\circ} \mathrm{C}$ kisaran suhu itu melebihi rata-rata suhu optimum untuk pertumbuhan ayam pedaging, sehingga perlu diupayakan mencari lokasi peternakan yang lebih tinggi agar suhu kandang tidak jauh berbeda dengan kebutuhan optimumnya (Oldeman dan Free, 1982). Wurlina dan Meles (2012) bahwa kandang closed house merupakan salah satu upaya yang dapat meminimalkan kontak langsung ayam dengan organisme lain dan memiliki pengaturan suhu, kelembaban dan ventilasi yang baik untuk menyediakan kondisi lingkungan yang nyaman bagi ternak.

Istiawan dan Kastono (2018) bahwa suatu daerah dapat dikatakan sebagai dataran rendah jika memiliki ketinggian sebesar $<400 \mathrm{~m}$ 
dpl, dataran sedang $400-7000 \mathrm{~m}$ dpl dan dataran tinggi $>700 \mathrm{~m} \mathrm{dpl}$. Pada tempat yang semakin tinggi dari atas permukaan laut suhu udaranya semakin rendah, sehingga ternak akan mengkonsumsi ransum lebih banyak untuk memenuhi kebutuhan akan energinya. Sugito dan Delima (2009) bahwa suhu lingkungan yang tinggi dapat menyebabkan pertumbuhan ayam broiler tidak maksimal. Untuk mengatasi tingginya suhu lingkungan pada setiap dataran dapat dilakukan dengan menggunakan kandang closed house.

Kandang closed house merupakan kandang tertutup yang sengaja dibuat dengan tujuan agar keadaan lingkungan luar seperti udara panas, hujan, angin, dan intensitas sinar matahari agar tidak memberikan pengaruh yang besar terhadap keadaan didalam kandang, akan tetapi dalam pelaksanaan dilapangan masih terdapat permasalahan dalam meminimalisir intervensi makroklimat kandang. Kondisi iklim dan cuaca makroklimat kandang sangat mempengaruhi kondisi mikroklimat kandang sehingga pertumbuhan bobot badan, bobot karkas, dan persentase karkas menjadi tidak maksimal (Kic et al., 2012).

Tujuan dari penelitian ini adalah untuk mengetahui pengaruh makroklimat terhadap mikroklimate dan produksi karkas ayam broiler. Manfaat dari pelaksanaan penelitian ini yaitu pertama untuk PT. Charoen Pokphan semoga hasil penelitian ini dapat dijadikan sebagai tolak ukur dalam mempersiapkan sistem pemeliharaan ayam broiler di kandang closed house untuk periode selanjutnya pada dataran yang berbeda. Kedua, bagi pembuka usaha peternakan ayam broiler yang menggunakan kandang closed house hasil penelitian ini dapat dijadikan pedoman dalam membuka usaha baru agar bisa mendapatkan hasil yang maksimal. Ketiga, bagi peneliti selanjutnya hasil penelitian ini dapat dijadikan referensi mengenai pengaruh tinggi dataran terhadap produksi karkas ayam broiler yang dipelihara di kandang closed house. Hipotesis penelitian ini adalah semakin tinggi tempat pemeliharaan ayam broiler akan meningkatkan bobot potong, bobot karkas, persentase karkas dan lemak abdominal karena pada tempat yang semakin tinggi dari atas permukaan laut suhu udaranya semakin rendah, sehingga ternak akan mengkonsumsi ransum lebih banyak untuk memenuhi kebutuhan.

\section{MATERI DAN METODE}

Penelitian ini dilaksanakan pada kandang closed house yang berada di wilayah dataran rendah, sedang dan dataran tinggi, untuk dataran rendah kandang yang dipilih yaitu yang berada di daerah Demak, dataran sedang yaitu Gunungpati dan daerah dataran tinggi yaitu daerah Ampel, Jawa Tengah. Pemilihan kandang didasarkan pada closed house yang memiliki prosedur manajemen pemeliharaan baik, sehingga semua kandang meskipun berada pada wilayah yang berbeda masih memiliki Standard Operation Procedure (SOP) yang sama dan baik.

Materi yang digunakan pada penelitian ini kandang closed house dari tiga dataran yaitu di wilayah Demak, Gunungpati dan Ampel. Metode yang dipakai dalam penelitian ini yaitu menggunakan Rancangan Acak Lengkap (RAL) dengan 3 perlakuan dan 8 ulangan sehingga terdapat 24 unit percobaan. Model matematik sebagai berikut:

$$
\begin{aligned}
& \text { Yij }=\mu+\tau i+\varepsilon i j ; \\
& \text { Keterangan : } \\
& \mathrm{i}=1,2,3 \quad \mathrm{t} \\
& \mathrm{j}=1,2,3 \ldots \mathrm{r}
\end{aligned}
$$

$$
\begin{array}{ll}
\text { Yij } & \text { : Produksi karkas dari perlakuan } \\
\text { dataran ke-i dan kelompok ke-j. } \\
\mu & \text { : Nilai tengah populasi (umum). } \\
\tau \text { i } & \text { : Pengaruh galat percobaan dari } \\
& \text { perlakuan dataran ke-i. } \\
\text { cij } \quad \text { Pengaruh galat percobaan dari } \\
\text { perlakuan dataran ke-i dan } \\
\text { kelompok ke-j. }
\end{array}
$$

Data yang diperoleh dianalisis ragam dengan uji $\mathrm{F}$ untuk mengetahui pengaruh tinggi tempat kandang. Apabila ada pengaruh perlakuan yang nyata $(\mathrm{p}<0,05)$ dilanjutkan dengan uji Duncan (Huda et al., 2017).

\section{HASIL DAN PEMBAHASAN}

\section{Bobot Potong}

Data bobot potong, produksi dan
persentase karkas, persentase lemak
abdominaldan evaluasi karkas ayam broiler yang
diperoleh dari hasil penelitian ditampilkan pada
Tabel 1 dan perhitungan statistik dengan
menggunakan analisis ragam.


Tabel 1. Rata-rata pengaruh perlakuan terhadap bobot potong, produksi dan persentase karkas

\begin{tabular}{llll}
\hline \multirow{2}{*}{\multicolumn{1}{c}{ Parameter }} & \multicolumn{3}{c}{ Rata - Rata } \\
\cline { 2 - 4 } & \multicolumn{1}{c}{$\mathrm{T} 1$} & \multicolumn{1}{c}{$\mathrm{T} 2$} & \multicolumn{1}{c}{$\mathrm{T} 3$} \\
\hline Bobot potong (g) & $1.560,13^{\mathrm{a}}$ & $1.477,94^{\mathrm{b}}$ & $1.454,38^{\mathrm{b}}$ \\
Bobot karkas (g) & $1.060,58^{\mathrm{a}}$ & $1.029,11^{\mathrm{ab}}$ & $1.006,01^{\mathrm{b}}$ \\
Persentase karkas (\%) & 67,96 & 69,64 & 69,15 \\
\hline
\end{tabular}

Sumber : Data Primer Hasil Penelitian di Dataran Rendah, Sedang dan Tinggi (2020)

Superskrip yang berbeda pada baris yang sama menunjukkan berbeda nyata $(p<0,05)$

Bobot potong adalah bobot yang didapat dengan cara menimbang bobot akhir ayam dan setelah dipuasakan selama 6-8 jam. Menurut Imamudin et al. (2012) bahwa pemotongan ayam dilakukan setelah ayam dipuasakan selama 8 jam dengan tujuan untuk mengosongkan saluran pencernaanya. Hasil analisis ragam menunjukkan bahwa perbedaan dataran berpengaruh nyata $(\mathrm{p}<0,05)$ terhadap bobot potong ayam broiler, dimana dataran rendah memiliki hasil yang lebih bagus sebesar 1.560,13 g dari dataran sedang sebesar 1.477,94 g maupun dataran tinggi sebesar 1.454,38 g. Menurut Pratama et al. (2015) bahwa pemeliharaan ayam broiler pada umur 28 - 35 hari memiliki bobot badan $1.400-$ $2.000 \mathrm{~kg} /$ ekor.

Faktor yang mempengaruhi bobot potong ayam broiler adalah kondisi makroklimat, mikroklimat kandang, kualitas dan kuantitas ransum serta jumlah ransum yang dikonsumsi. Pada suhu rendah akan menyebabkan kelembaban menjadi tinggi sehingga kandang akan menjadi bau karena adanya pertumbuhan mikroorganisme pada sekam sementara suhu yang tinggi akan menyebabkan kelembaban dalam kandang akan semakin rendah sehingga ayam akan mengalami dehidrasi. Menurut Woro et al. (2019) bahwa suhu dan kelembaban yang tinggi akan menyababkan ayam kesulitan dalam menyeimbangkan panas tubuhnya sehingga ayam dapat mengalami stress. Menurut Miles et al. (2011) bahwa kondisi litter yang lembab memberikan kondisi yang optimal bagi bakteri untuk mengubah uric acid menjadi amonia sehingga memberikan dampak peningkatan amonia litter. Apabila kondisi amonia didalam kandang tinggi, akan menyebabkan timbulnya berbagai penyakit yang dapat membahayakan kesehatan ayam. Menurut Marang et al. (2019) bahwa apabila kadar amonia didalam kandang terlalu tinggi maka akan memicu timbulnya berbagai penyakit yang dapat membahayakan ayam.

Kondisi mikroklimat yang dihasilkan pada kandang yaitu untuk Demak memiliki suhu $32,575{ }^{\circ} \mathrm{C}$, kelembaban $60,296 \%$ dengan kecepatan angin $511,12 \mathrm{ft} / \mathrm{min}$ sementara di Gunung pati memiliki suhu $28,169^{\circ} \mathrm{C}$, kelembaban 77,491\% dengan kecepatan angin 586,59 $\mathrm{ft} / \mathrm{min}$ dan Ampel memiliki suhu $28,535^{\circ} \mathrm{C}$ kelembaban $73,753 \%$ dengan kecepatan angin $344,56 \mathrm{ft} / \mathrm{min}$, dari semua kondisi mikroklimat yang ada, suhu efektif yang dapat dirasakan oleh ayam yaitu Demak $23^{\circ} \mathrm{C}$, Gunung pati $22^{\circ} \mathrm{C}$ dan Ampel $25^{\circ} \mathrm{C}$. Pada dataran rendah memiliki suhu yang paling tinggi namun bobot badan yang dicapai ayam lebih baik dari dataran sedang dan tinggi, hal ini dikarenakan memiliki suhu efektif dan heat index yang optimal. Berdasarkan data suhu dan kelembaban yang diperoleh dapat dikalkulasi untuk mengetahui heat index pada ayam yaitu pada wilayah Demak 150, Gunungpati 160 dan Ampel 157. Berdasarkan kondisi ini ayam yang berada pada derah Demak berada pada kondisi

Tabel 2. Rata-rata pengaruh perlakuan terhadap suhu, kelembaban, kecepatan angin, heat index dan suhu efektif

\begin{tabular}{lccc}
\hline \multicolumn{1}{c}{ Parameter } & Demak & Gunungpati & Ampel \\
\hline Suhu & $32^{\circ} \mathrm{C}$ & $28^{\circ} \mathrm{C}$ & $28^{\circ} \mathrm{C}$ \\
Kelembaban & $60 \%$ & $77 \%$ & $73 \%$ \\
Kecepatan angin & $511 \mathrm{ft} / \mathrm{min}$ & $586 \mathrm{ft} / \mathrm{min}$ & $344 \mathrm{ft} / \mathrm{min}$ \\
Heat Index & 150 & 160 & 157 \\
Suhu efektif & $23^{\circ} \mathrm{C}$ & $22^{\circ} \mathrm{C}$ & $25^{\circ} \mathrm{C}$ \\
\hline
\end{tabular}

Sumber : Wahyuningrum (2020) 
yang optimal sementara pada Gunungpati dan Ampel termasuk kedalam kondisi toleransi. Menurut Yasa et al., 2019 bahwa heat index 150 termasuk kedalam kondisi optimal dimana tidak terjadi permasalahan performance, sementara pada heat index sebesar 155 - 160 tergolong dalam kondisi toleransi dimana pada ayam akan terjadi penurunan feed intake, peningkatan water intake, dan penurunan performance.

Menurut Oktaviana et al. (2010) bahwa bobot badan potong ayam broiler dipengaruhi oleh suhu efektif yang baik sehingga memberikan dampak yang baik dalam konsumsi dan pencernaan ayam terhadap pakan yang diberikan. Bobot potong ayam broiler kaitannya sangat erat dengan konsumsi ransum dan lemak abdominal serta kecernaan ayam broiler. Menurut Kiramang (2011) bahwa ayam akan mengkonsumsi ransum sesuai dengan energi yang dibutuhkan apabila energi yang dibutuhkan tubuh sudah terpenuhi maka ayam akan berhenti makan. Apabila konsumsi ransum ayam broiler tinggi maka bobot potong ayam juga akan tinggi, sementara jika konsumsi ransum rendah maka bobot potong ayam yang dihasilkan akan kecil. Menurut Syahruddin et al. (2012) bahwa suhu lingkungan yang tinggi dapat menimbulkan dampak negatif pada kondisi fisiologis dan produktivitas ayam broiler, karena pada suhu yang tinggi ayam akan mengalami stres panas yang dapat mengakibatkan penurunan konsumsi pakan.

Suhu mikroklimat kandang pada siang hari berkisar antara $29^{\circ} \mathrm{C}-35^{\circ} \mathrm{C}$ kondisi ini masih tergolong tinggi karena suhu lingkungan yang baik untuk pemeliharaan ayam yang berumur diatas 20 hari yaitu $20^{\circ} \mathrm{C}-25^{\circ} \mathrm{C}$, untuk mengatasi permasalahan ini yaitu dengan melakukan modifikasi mikro untuk memperoleh suhu efektif. Menurut Rose (1997) bahwa suhu efektif untuk pemeliharaan ayam broiler yaitu $18^{\circ} \mathrm{C}-24^{\circ} \mathrm{C}$. Modifikasi mikro yang dilakukan yaitu dengan memakai blower berjumlah 6 buah yang dapat menyala secara otomatis pada saat suhu kandang terlalu tinggi sehingga ayam tidak mengalami stres yang dapat menurunkan performanya. Pada saat suhu tinggi maka secara otomatis blower akan menyala untuk menarik panas keluar dari kandang sehingga kondisi kandang dapat memberikan suhu yang nyaman bagi ayam. Apabila kondisi didalam kandang terlalu panas maka ayam dapat mengalami stress, ayam sudah mengalamai stress cenderung akan menurunkan konsumsi pakan untuk mengurangi aktivitas metabolisme, dimana aktivitas metabolisme dapat meningkatkan panas tubuh, salah satu upaya untuk mengeluarkan panas didalam tubuh biasanya ayam akan melakukan panting dan meningkatkan konsumsi air minum, apabila konsumsi pakan menurun maka kebutuhan nutrisi untuk pertumbuhan akan berkurang sehingga akan akan mengganggu pertumbuhannya. Menurut Sulistyoningsih et al. (2016) bahwa suhu yang lebih panas dari suhu normal akan menyebabkan stres pada ayam broiler dan berdampak terhadap pertumbuhan ayam.

\section{Bobot Karkas}

Hasil analisis ragam menunjukkan bahwa perbedaan dataran berpengaruh nyata $(\mathrm{p}<0,05)$ terhadap produksi bobot karkas ayam broiler, dimana dataran rendah memiliki hasil yang lebih bagus dari dataran tinggi namun tidak berbeda dengan dataran sedang. Hal ini disebabkan oleh perbedaan makroklimat yang berbeda pada setiap dataran, sehingga mempengaruhi suhu efektif yang dirasakan ayam di dalam kandang, apabila suhu efektif tidak tercapai maka bobot potong yang dihasilkan berbeda beda. Menurut Haroen (2003) bahwa bobot karkas memiliki kaitan yang sangat dengan bobot potong dan pertumbuhan bobot badan.

Menurut Nahashon et al. (2005) bahwa bobot karkas sangat dipengaruhi oleh bobot hidup yang dihasilkan. Semakin tinggi bobot hidup, bobot karkas akan semakin tinggi begitu juga sebaliknya. Menurut Resnawati (2004) bahwa bobot karkas yang di hasilkan dipengaruhi oleh beberapa faktor yaitu kondisi makroklimat dan mikroklimat kandang, umur, jenis kelamin, bobot potong, besar dan konformasi tubuh, perlemakan, kualitas dan kuantitas ransum serta strain yang dipelihara. Bobot karkas yang diperoleh pada penelitian ini yaitu pada dataran rendah $1.060,58 \mathrm{~g}$, pada dataran sedang 1.029,11 $\mathrm{g}$ dan dataran tinggi 1.006,01 g atau sekitar 69$70 \%$ dari bobot hidup. Hal ini menunjukkan produksi karkas masih berada pada kisaran normal. Menurut Sari et al. (2014) bahwa rata rata berat karkas ayam broiler berkisar antara 6575\% dari bobot hidup. Menurut Ihsan (2006) yang bahwa bobot karkas ayam broiler pada umur 4 minggu yaitu $932-1.225$ gram.

Pertumbuhan ayam broiler dipengaruhi oleh faktor genetik dan lingkungan. Menurut Risnajati (2012) bahwa pertumbuhan seekor ternak merupakan interaksi antara faktor genetik dan faktor lingkungan, dengan sumbangan faktor lingkungan lebih dominan dari faktor genetik. 
Suhu mikroklimat kandang pada siang hari berkisar antara $29^{\circ} \mathrm{C}-35^{\circ} \mathrm{C}$ kondisi ini masih tergolong tinggi. Menurut Rao et al. (2002) bahwa pemeliharaan unggas didaerah tropis, suhu lingkungan merupakan faktor yang sangat menmpengaruhi pertumbuhan ayam, suhu yang ideal dalam pemeliharaan ayam broiler yaitu 10 $22^{\circ} \mathrm{C}$ untuk mencapai bobot badan yang optimum dan $15-27^{\circ} \mathrm{C}$ untuk efisiensi ransum. Pada suhu yang tinggi akan menyebabkan kelembaban dalam kandang akan semakin rendah sehingga ayam akan mengalami dehidrasi, sementara jika suhu rendah maka akan menyebabkan kelembaban menjadi tinggi sehingga kandang akan menjadi bau karena adanya pertumbuhan mikroorganisme pada sekam. Menurut Woro et al. (2019) bahwa suhu dan kelembaban yang tinggi akan menyababkan ayam kesulitan dalam membuang panas tubuhnya sehingga ayam dapat mengalami stress.

\section{Persentase Karkas}

Berdasarkan tabel diatas diketahui bahwa perbedaan dataran tidak berpengaruh nyata $(p>0,05)$ terhadap persentase karkas yaitu pada dataran rendah sebesar $67,96 \%$, dataran sedang $69,64 \%$ dan pada dataran tinggi $69,15 \%$. Hal ini menunjukkan bahwa persentase karkas masih dalam taraf normal. Menurut Subekti et al. (2012) bahwa persentase karkas ayam broiler pada 28-35 hari berada diantara $65-75 \%$ dari bobot hidup. Faktor yang mempengaruhi persentase karkas yaitu bobot akhir ayam, genetik, komposisi ransum dan suhu lingkungan. Pada temperatur yang rendah akan memberikan dampak kelembaban yang meningkat, sehingga pada kondisi ini ayam akan mengalami stress karena kedinginan dan ayam juga akan kesulitan dalam membuang panas tubuhnya sementara pada temperatur yang tinggi ayam akan mengalami stress panas sehingga akan terjadi penurunkan nafsu makan karena ayam akan berusaha mengeluarkan panas tubuh melalui panting.

Menurut Subekti et al. (2012) bahwa suhu lingkungan yang tinggi dapat mengurangi laju pertumbuhan unggas. Ayam broiler tumbuh dengan cepat dan mampu mengubah makanan yang dimakan menjadi daging dengan sangat effisien, kemampuan ini akan berjalan optimal pada suhu lingkungan yang sesuai. Menurut Subekti et al. (2012) bahwa pada saat ayam mengalami stres panas, maka ayam akan menurunkan konsumsi pakan yang akan memberikan dampak pencapaian bobot badan akhir tidak maksimal, sehingga mempengaruhi pencapaian terhadap bobot karkas menjadi tidak maksimal pula. Bobot karkas sangat berpengaruh terhadap bobot akhir pada ayam broiler. Faktor yang mempengaruhi persentase bobot karkas adalah kondisi makroklimat dan mikroklimat kandang, bangsa, umur jenis kelamin, bobot badan, dan konsumsi. Menurut Subekti et al. (2012) yang bahwa faktor yang mempengaruhi karkas adalah umur, jenis kelamin, dan bobot badan. Menurut Soeparno (1994) bahwa faktor lingkungan mempengaruhi laju pertumbuhan, komposisi bobot karkas dan persentase karkas biasanya meningkat seiring dengan meningkatnya bobot hidup ayam.

\section{Persentase Lemak Abdominal}

Berdasarkan Tabel 3 diketahui bahwa perbedaan dataran tidak berpengaruh nyata ( $>00,05)$ terhadap persentase lemak abdominal. Persentase lemak abdominal yang diperoleh dari penelitian ini yaitu pada dataran rendah sebesar $2,10 \%$, dataran sedang $2,15 \%$ dan pada dataran tinggi 2,14\%. Hal ini menunjukan bahwa lemak abdominal yang dihasilkan masih tergolong normal.

Tabel 3. Rata-rata pengaruh perlakuan terhadap persentase lemak abdominal dan kualitas karkas

\begin{tabular}{lccc}
\hline \multirow{2}{*}{ Parameter } & \multicolumn{3}{c}{ Rata - Rata } \\
\cline { 2 - 4 } & T1 & T2 & T3 \\
\hline Persentase lemak & 2,10 & 2,15 & 2,14 \\
Abdominal (\%) & & B & B \\
Evaluasi karkas & B &
\end{tabular}

Sumber : data primer hasil penelitian di dataran rendah, sedang dan tinggi (2020).

Menurut Salam et al. (2013) bahwa standar lemak abdominal pada ayam broiler berkisan antara $0,73 \%$ sampai $3,78 \%$. Faktor yang mempengaruhi pembentukan lemak abdominal yaitu jenis kelamin, kandungan nutrisi ransum, suhu lingkungan. Kondisi suhu lingkungan dapat mempengaruhi banyak sedikitnya lemak abdominal, apabila suhu lingkungan tinggi maka menyebabkan suhu tubuh ayam akan semakin panas kemudian akan membuat ayam lebih banyak minum dari pada mengkonsumsi pakan. Menurut Dewanti et al. (2013) bahwa pertumbuhan lemak abdominal dapat dipengaruhi oleh beberapa faktor seperti umur, jenis kelamin, kandungan nutrisi dalam 
ransum dan kemampuan ternak dalam mencerna ransum untuk mendapatkan energi yang sesuai dibutuhkan oleh tubuh ternak.

Menurut Setiawan dan Sujana (2009) bahwa pembentukan lemak didalam tubuh ayam dapat terjadi karena adanya kelebihan energi yang dikonsumsi. Energi yang digunakan oleh tubuh pada umumnya berasal dari karbohidrat dan cadangan lemak. Sumber karbohidrat yang terdapat didalam tubuh mampu memproduksi lemak yang biasanya akan tersimpan di sekeliling jeroan dan dibawah kulit. Pertumbuhan lemak pada ayam broiler yang berumur 28 hari belum terlalu banyak karena energi yang terdapat didalam tubuh masih banyak digunakan untuk proses pertumbuhan. Menurut Kusuma et al. (2014) bahwa ayam broiler pada umur 21-33 hari pembentukan lemak abdominalnya belum terlalu banyak hal ini disebabkan oleh zat-zat makanan yang diserap oleh tubuh masih banyak digunakan untuk pertumbuhan ayam. Pertumbuhan lemak abdominal dapat meningkat jika bobot badan yang dihasilkan mengalami peningkatan. Menurut Gultom. (2012) bahwa bobot lemak abdominal akan mengalami peningkatan dengan bertambahnya bobot badan, dan sebaliknya apabila bobot badan kecil maka bobot lemak abdominalnya akan menjadi kecil sehingga persentase lemak abdominalnya akan menjadi kecil.

\section{Evaluasi Karkas}

Evaluasi karkas ayam merupakan penilaian yang dilakukan berdasarkan informasi tubuh ayam meliputi bagian dada, bagian punggung, bagian paha serta bagian sayap ayam dan penilaian terhadap perdagangan, lemak pada tubuh, kondisi kulit dan bulu ayam. Hal-hal yang perlu dilakukan evaluasi yaitu bentuk konfirmasi karkas, dan penampilan karkas. Menurut Koswara (2009) bahwa evaluasi karkas adalah mengevaluasi bagian tubuh ayam setelah pemotongan kemudian dikurangi bagian kepala, bulu, jeroan, kaki dan darah.

Berdasarkan Tabel 3. diatas diketahui bahwa kualitas karkas yang berasal dari daerah Demak, Gunungpati dan Ampel memiliki kualitas yang sama yaitu sedang (B) yaitu ayam memiliki kondisi tulang dada, punggung, paha dan sayap dalam kondisi sedang, tidak lurus dan tidak bengkok. Faktor yang mempengaruhi kualitas karkas yaitu suhu makroklimat dan mikroklimat kandang, apabila suhu terlalu tinggi sehingga dapat membuat ayam menjadi stress dan akan memberikan dampak proses pertumbuhan ayam seperti pada keserasian tulang dada, tulang punggung dan tulang paha dengan sayap. Menurut Matulessy (2010) yang bahwa nilai karkas dipengaruhi oleh berat karkas, jumlah daging yang dihasilkan, keserasian tulang dada, punggung serta paha dengan sayap.

\section{KESIMPULAN}

Pemeliharaan ayam broiler pada kandang closed house pada dataran yang berbeda berpengaruh terhadap kondisi kelembaban, dan suhu efektif yang dirasakan oleh ayam didalam kandang, sehingga menghasilkan bobot potong dan produksi karkas ayam broiler yang paling baik pada dataran rendah.

\section{DAFTAR PUSTAKA}

Dewanti, R., M. Irham dan Sudiyono. 2013. Pengaruh penggunaan eceng gondok (Eichornia crassipes) terfermentasi dalam ransum terhadap persentase karkas, nonkarkas dan lemak abdominal itik lokal jantan umur delapan minggu. Buletin Peternakan. 37(1): 19-25.

Gultom, S. M., H. Supratman dan Abun. 2012. Pengaruh imbangan energi dan protein ransum terhadap bobot karkas dan bobot lemak abdominal ayam broiler umur 3- 5 minggu. Jurnal Agrik. 1 (1): 1-5.

Imamudin, U. Atmomarsono dan M. H. Nasoetion. 2012. Pengaruh Berbagai Frekuensi Pemberian Pakan Pada Pembatasan Pakan terhadap Produksi Karkas Ayam Broiler. Animal Agricultural Journal 1(1): 87 - 98.

Koswara, S. 2009. Pengolahan Unggas. Jurnal Pangan 3(1): $22-40$.

Kusuma, R. A., B. Dwiloka dan L. D. Mahfudz. 2014. Berat karkas, nonkarkas dan lemak abdominal pada ayam broiler yang diberi pakan mengandung Salvinia molesta. Animal Agriculture Journal. 3(2): 249257.

Haroen, U. 2003. Respon ayam broiler yang diberi tepung daun sengon (Albizzia falcataria) dalam ransum terhadap pertumbuhan dan hasil karkas. Jurnal 
Ilmiah Ilmu-ilmu Peternakan 6 (1): 3441.

Huda, N., Djufri dan Laili. S. 2017. Perbandingan Perendaman Ekstrak Kulit Pisang Raja (Musa paradisiaca Var. Raja) dan Ekstrak Kulit Pisang Kepok (Musa acuminate) terhadap Karakteristik Organoleptik dan Fisik Daging Ayam Kampung (Gallus domesticus). Jurnal Ilmiah Mahasiswa Fakultas dan Ilmu Pendidikan Unsyiah 2(1): 63 - 77.

Ihsan, F.N. 2006. Persentase bobot karkas, lemak abdomen, dan organ dalam ayam broiler dengan pemberian silase ransum komersial. Skripsi. Fakultas Pertanian. Institut Pertanian Bogor, Bogor.

Istiawan dan Kastono. 2018. Pengaruh Ketinggian Tempat Tumbuh terhadap Hasil dan Kualitas Minyak Cengkih (Syzygium aromaticum (L.) Merr. \& Perry.) di Kecamatan Samigaluh, Kulon Progo. Vegetalika. 8 (1): 27 - 41.

Kic, P., L. Ruzek, Z. Levinka, L. Zita, and I. Gardianova. 2012. Pollution of indoor environment in poultry housing. In: 11 th International Scientific Conference Engineering for Rural Development. Latvia University of Agriculture, Jelgava. 480-483.

Kiramang, K. 2011. Berat Badan Akhir, Konversi Ransum dan Income Over Feed dan Chick Cost Ayam Broiler dengan Pemberian Ransum Komersial. Jurnal Teknosains 5 (1): 15-25.

Matulessy, D. N., E, Suryanto dan Rusman. 2010. Evaluasi karakteristik fisik, komposisi kimia dan kualitas mikrobia karkas broiler beku yang beredar di pasar tradisional Kabupaten Halmahera Utara, Maluku Utara. Jurnal Buletin Peternakan 34 (3) : $178-185$.

Marang, E.A.F., L.D. Mahfudz., T.A. Sarjana dan S. Setyaningrum. 2019. Kualitas dan Kadar Amonia Litter Akibat Penambahan Sinbiotik dalam Ransum Ayam Broiler. Jurnal Peternakan Indonesia. 21(3): 303 310.
Miles, D.M., D.E. Rowe and T.C. Cathcart. 2011. Litter ammonia generation: moisture content and organic versus inorganic bedding materials. Poultry Science 90 (6): 1162-1169.

Nahashon, S. N., N. Adefope, A. Amenyenu and D. Wright. 2005. Effects of dietary metabolizable energy and crude protein concentration on growth performance and carcass characteristics of French guinea broiler. Poult. Sci. 84 : 337-344.

Oktaviana, D., Zuprizal dan E, Suryanto. 2010. Pengaruh Penambahan Ampas Virgin Coconut Oil Dalam Ransum Terhadap Performans dan Produksi Karkas Ayam Broiler. Buletin Peternakan 34 (3) : 159 164.

Oldeman, L. R. and M. Free. 1982. A study of the agroclimatology of the Hummid Tropics of Southeatst Asia. FAO/UNESCO/WMO interagency project on.

Pratama, A., S. Kusmayadi, L. B. Roostita, C. Hartati, A. W. L. Hendronoto, S. S. Denny, S. Lilis, G. Jajang, W. Eka, S. P. Wendry. 2015. Evaluasi karakteristik sifat fisik karkas ayam broiler berdasarkan bobot badan hidup. Jurnal Ilmu Ternak 15 (2): 61 - 64.

Rao, R. S. V., D. Nagalashmi dan V. R. Redy. 2002. Feeding to minimize heat stress. Jurnal Poultry Int. 41: 7-15

Resnawati, H. 2004. Bobot potongan karkas dan lemak abdomen ayam ras pedaging yang diberi ransum mengandung tepung cacing tanah (Lumbricus rubellus). Balai Penelitian Ternak. Bogor

Rose, P. S. 1997. Principles of Poultry Science, page 117, Cab International, New York, US.

Risnajati, D. 2012. Perbandingan Bobot Akhir, Bobot Karkas dan Persentase Karkas Berbagai Strain Broiler. Jurnal Sains Peternakan 10 (1): 11 - 14.

Salam, S., A. Fatahillah, D. Sunarti dan Isroli. 2013. Bobot Karkas dan Lemak 
Abdominal yang Diberi Tepung Jintan Hitam (Nigella Sativa) dalam Ransum selama Musim Panas. Jurnal Sains Peternakan 11(2): $84-89$.

Sari, M. L., N. L. Fitri, dan D. J. Lia, 2014. Pengaruh pemberian asap cair melalui air minum terhadap kualitas karkas ayam broiler. Jurnal Agripet. 14 (1): 71-75.

Setiawan, I. dan E. Sujana. 2009. Bobot akhir, persentase karkas dan lemak abdominal ayam broiler yang dipanen pada umur yang berbeda. Seminar Nasional Fakultas Peternakan Universitas Padjadjaran Pengembangan Sistem Produksi dan Pemanfaatan Sumberdaya Lokal untuk Kemandirian Pangan Asal Ternak.

Sugito dan M. Delima. 2009. Dampak cekaman panas terhadap pertambahan bobot badan, rasio heterofil: limfosit dan suhu tubuh ayam broiler. J. Ked. Hewan. 1 (3) : $218-226$.

Soeparno. 1994. Ilmu dan Teknologi Daging. Gadjah Mada University Press, Yogyakarta.

Subekti, K., H. Abbas dan K. A. Zura. 2012. Kualitas karkas (berat karkas, persentase karkas, dan lemak abdominal) ayam broiler yang diberi kombinasi $\mathrm{CPO}$ (crude palm oil) dan vitamin $\mathrm{C}$ (ascorbic acid) dalam ransum sebagai anti stress. Jurnal Peternakan Indonesia 14 (3): 447 453.
Sulistyoningsih, M., R. Reni dan A. Dewi. 2016. Kajian Kualitas Performans (Bobot Badan, Karkas, dan Lemak Abdominal) Ayam Broiler pada Beberapa Peternakan Rakyat. Prosiding Seminar Nasional Hasil Penelitian Lembaga Penelitian dan Pengabdian kepada Masyarakat Universitas PGRI Semarang, Semarang. $77-95$.

Syahruddin, Yatno, N. Ramli, K. G. Wiryawan. 2008. Mannan Polysaccharides in Byproducts of Protein Concentrate from Palm Kernels as Eschericia coli Control. Seminar Nasional Teknologi Peternakan dan Veteriner. Bogor (ID): Institut Pertanian Bogor.

Woro, I. D, U. Atmomarsono dan R. Muryani. 2019. Pengaruh pemeliharaan pada kepadatan kandang yang berbeda terhadap performa ayam broiler. Jurnal Sain Peternakan Indonesia 14 (4): 418 423.

Wurlina, dan D. K. Meles. 2012. Teknologi Kandang Tertutup (Closed House) terhadap Berat Badan, Mortalitas dan Waktu Panen Ayam Pedaging. Veterinaria Medika 5(3): 215-218

Yasa, I. M. S., I. K. Darminta dan I. K. Ta. 2019. Kontrol heat stress index ruangan ayam broiler pada periode brooding secara otomatis berbasis Arduino-Uno. Jurnal Politeknologi 18 (2): $151-158$. 